\title{
The Nogo-Nogo Receptor Pathway Limits a Spectrum of Adult CNS Axonal Growth
}

\author{
William B. J. Cafferty and Stephen M. Strittmatter \\ Program in Cellular Neuroscience, Neurodegeneration, and Repair, Yale University School of Medicine, New Haven, Connecticut 06510
}

The hypothesis that Nogo-A (Reticulon 4A) and Nogo-66 receptor (NgR1) limit adult CNS axonal growth after injury is supported by both in vitro experiments and in vivo pharmacological studies. However, genetic assessment of the role of Nogo-A in corticospinal tract (CST) axons after spinal cord dorsal hemisection has yielded conflicting results. CST regeneration is detected in homozygous nogo-ab ${ }^{\text {trap/trap }}$ mice, but not in nogo- $a b^{\text {atg/atg }}$ mice. CST regeneration is also present after pharmacological NgR blockade, but not in $n g r 1^{-1-}$ mice. To assess the nogo- $a b^{\text {atg }}$ and $n g r 1$-null alleles for other axon growth phenotypes, we created unilateral pyramidotomies and monitored the uninjured CST. There is robust pyramidotomy-induced growth of nogo-a $b^{\text {atg/atg }}$ and $n g r 1^{-/-}$CST axons into denervated cervical gray matter. This fiber growth correlates with recovery of fine motor skill in the affected forelimb. Thus nogo-ab and ngr 1 play a modulated role in limiting CNS axonal growth across a spectrum of different tracts in various lesion models.

Key words: axon regeneration; corticospinal; Nogo; gene targeting; myelin; plasticity

\section{Introduction}

Axons extend over long distances during development to wire the nervous system. As the brain and spinal cord mature, axonal growth in the mammalian brain is refined by experience and then severely restricted in the adult. Although stability of axonal connections may facilitate complex brain function, lack of axonal growth limits brain and spinal cord repair after acquired neurological injury. The extension of adult CNS axons for long distances in vivo through peripheral nerve grafts has led to the hypothesis that CNS glial cells present proteins inhibitory for axonal growth (David and Aguayo, 1981; Benfey and Aguayo, 1982). Four proteins have been identified as myelin-associated inhibitors: Nogo (Chen et al., 2000; GrandPre et al., 2000; Prinjha et al., 2000), myelin-associated glycoprotein (MAG) (McKerracher et al., 1994; Mukhopadhyay et al., 1994), oligodendrocyte myelin glycoprotein (OMgp) (K. Wang et al., 2002), and ephrinB3 (Benson et al., 2005). Three of these myelin ligands bind with high affinity to the Nogo-66 receptor (NgR) (Fournier et al., 2001; Liu et al., 2002; K. Wang et al., 2002; Venkatesh et al., 2005). Here we use the term NgR1 for NgR to distinguish it from two related proteins, $\mathrm{NgR} 2$ and $\mathrm{NgR} 3$ (Barton et al., 2003), the former of which can function as an alternative MAG receptor (Venkatesh et al., 2005).

Nogo is a member of the Reticulon family (Rtn-4) and exists in $\mathrm{A}, \mathrm{B}$, and $\mathrm{C}$ isoforms. In the adult CNS Nogo-A is enriched in oligodendrocytes and myelin, whereas Nogo-C is expressed by neurons and Nogo-B is much less abundant. Each isoform con-

Received Sept. 2, 2006; revised 0ct. 12, 2006; accepted 0ct. 13, 2006.

This work is supported by research grants from the Christopher Reeve Paralysis Foundation, the Falk Medical Research Trust, and the National Institutes of Health to S.M.S.

Correspondence should be addressed to Stephen M. Strittmatter, Department of Neurology, Yale University School of Medicine, P.0. Box 208018, New Haven, CT 06510. E-mail: stephen.strittmatter@yale.edu.

DOI:10.1523/JNEUROSCI.3827-06.2006

Copyright $\odot 2006$ Society for Neuroscience $\quad$ 0270-6474/06/2612242-09\$15.00/0 centrates in the endoplasmic reticulum, but Nogo-A reaches the surface of oligodendrocytes and Nogo-B that of endothelial cells in significant amounts (GrandPre et al., 2000; Acevedo et al., 2004; Dodd et al., 2005; Voeltz et al., 2006). Oligodendrocyte Nogo-A juxtaposed to axonal NgR (X. Wang et al., 2002) provides bipartite activation of $\mathrm{NgR}$ to inhibit axonal growth (Hu et al., 2005). Nogo-A has additional inhibitory actions via receptors not shared with Nogo-B or Nogo-C (Fournier et al., 2001; Oertle et al., 2003; Acevedo et al., 2004; Miao et al., 2006).

Pharmacological studies have demonstrated benefit from interfering with Nogo/NgR function on axonal regeneration and functional recovery after spinal cord injury (SCI) (Schnell and Schwab, 1990; Bregman et al., 1995; GrandPre et al., 2002; Li et al., 2004). Similar benefits are noted for stroke recovery (Papadopoulos et al., 2002; Lee et al., 2004; Seymour et al., 2005). Genetic analysis has proven less clear (Woolf, 2003). Three laboratories have generated Nogo-A knock-out mice, two of which, termed nogo-a $b^{\text {trap/trap }}$ (Kim et al., 2003) and nogo- $a^{\text {EIII/EIII }}$ (Simonen et al., 2003; Dimou et al., 2006) in this publication, showed enhanced growth of corticospinal tract (CST) axons after spinal hemisection. In contrast, one mouse, termed nogo- $a b^{\text {atg/atg }}$ here, failed to show an enhanced regenerative phenotype (Zheng et al., 2003). In our laboratory a direct comparison of dorsal hemisection in littermate-matched, strain-identical nogo- $a b^{\text {trap/trap }}$ versus nogo-ab atg/atg mice confirms a phenotypic difference between these alleles, with clear long-distance CST regeneration in the mice carrying the trap allele, but not the atg allele (our unpublished studies).

The confusion from divergent nogo genetic studies has been compounded by the observation that mutant mice lacking NgR1 do not show an enhanced CST regenerative phenotype after dorsal hemisection (Kim et al., 2004; Zheng et al., 2005). However, the $n g r 1^{-/-}$phenotype is complex in that these mice do recover hindlimb function after spinal injury and show regeneration of 
A
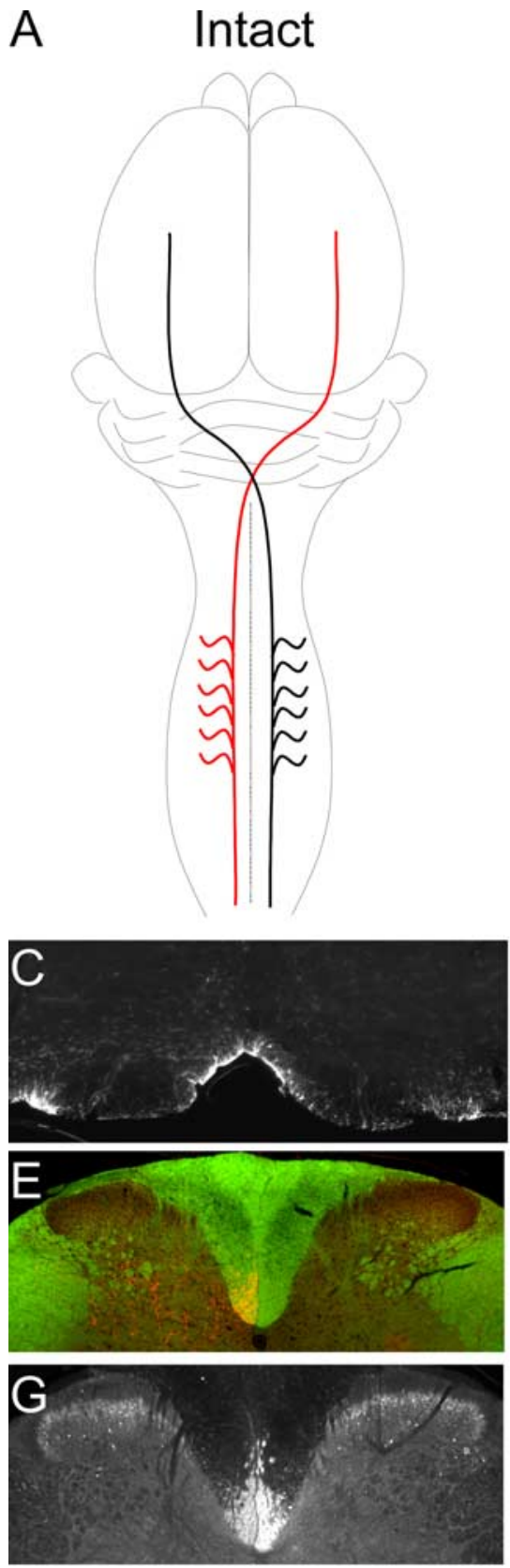
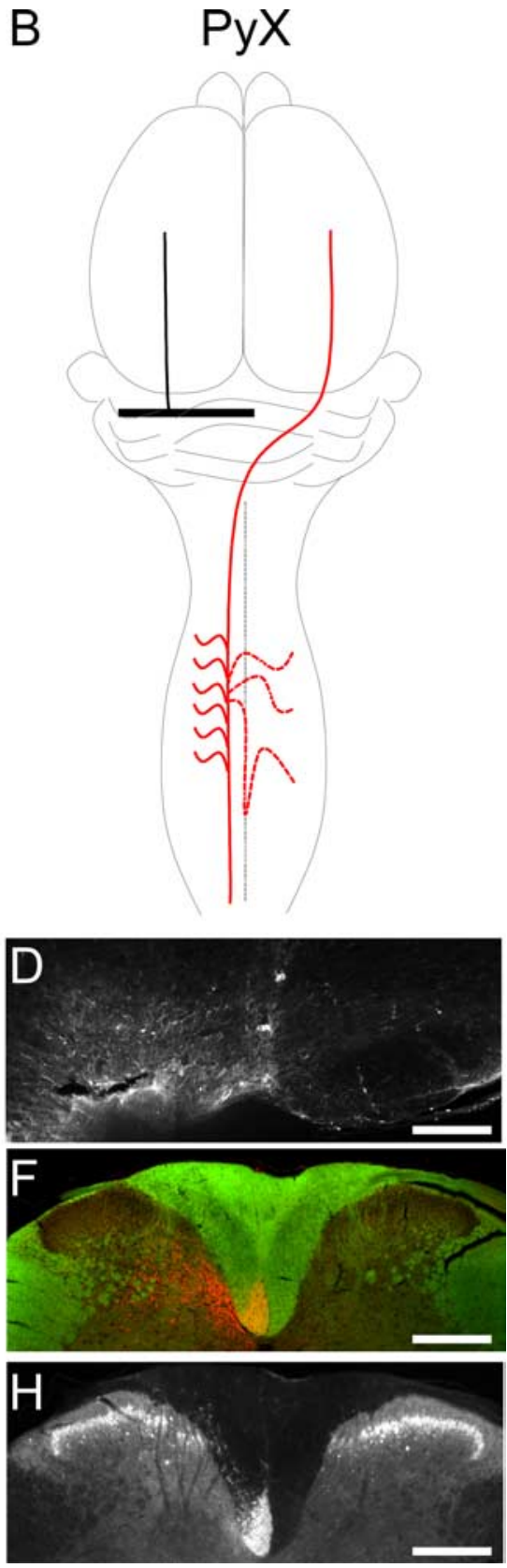

Figure 1. PyX ablates corticospinal input along one side of the spinal cord. Schematic of brain and spinal cord illustrating mature termination pattern of the adult CST $(\boldsymbol{A})$ and location of lesion and predicted sprouting response from intact CST $(\boldsymbol{B})$ into deafferented side (stippled line). Photomicrographs $\boldsymbol{C}, \boldsymbol{E}$, and $\mathbf{G}$ show brainstem, cervical, and lumbar spinal cord, respectively, from intact wild-type animals and $\boldsymbol{D}, \boldsymbol{F}$, and $\boldsymbol{H}$ from pyramidotomized wild-type animals. Anti-GFAP-reactive astrocytes demarcate the lesion (D), but no astrocytic response is evident in sham-lesioned animals ( $($ ). Scale bar, $200 \mu \mathrm{m}$. Sections from C 7 spinal cord of naive $(\boldsymbol{E})$ and PyX wild-type $(\boldsymbol{F})$ animals illustrate an identical termination pattern of BDA ${ }^{+}$CST axons (red) and myelin compaction (green). Scale bar, $200 \mu \mathrm{m}$. Inspection of $\mathrm{L} 4$ spinal cord shows bilateral PKC $\gamma$ immunoreactivity in the ventrodorsal columns of intact mice $(\boldsymbol{G})$ and unilateral PKC $\gamma$ immunoreactivity in PyX mice $(\boldsymbol{H})$. Scale bar, $200 \mu \mathrm{m}$.

rubrospinal and raphespinal axons (Kim et al., 2004). Against this background of consistently positive pharmacological studies but varied genetic results, we have undertaken a more complete analysis of the seemingly nonregenerative CST in $\mathrm{ngr}^{-/-}$mice (Kim et al., 2004) and nogo-ab $b^{\text {atg/atg }}$ mice (Zheng et al., 2003). We find that the lack of a CST growth phenotype is relative, and not absolute, in nogo-ab atg/atg and $n g r^{-1-}$ mice. In a selective pyramidotomy paradigm there is pronounced collateral sprouting of intact CST fibers across the midline and into denervated spinal cord, with a return of preferred forelimb usage in both $n g r 1^{-1-}$ and nogo-ab atg/atg mice. These data confirm a role for Nogo-A and NgR1 in limiting functional recovery from SCI via a spectrum of axonal growth within the damaged CNS.

\section{Materials and Methods}

Mice. Nogo- $a b^{\text {atg/atg }}$ mice were a gift from Marc Tessier-Lavigne (Zheng et al., 2003). $\mathrm{Ngr}^{-/-}$ mice have been described (Kim et al., 2004). Both lines were back-crossed with C57/BlK6 for more than six generations, and mice were 7-9 weeks of age at surgery. Wild-type littermates were used as controls.

Surgery. Animals were anesthetized deeply with ketamine $(100 \mathrm{mg} / \mathrm{kg}) / x y l a z i n e ~(15 \mathrm{mg} /$ $\mathrm{kg})\left[n=50\left(15=n g r 1^{-/-}, 10=n g r 1^{+/+}, 15=\right.\right.$ nogo-ab atg/atg , and $10=$ nogo- $\left.\left.a b^{+/+}\right)\right]$and placed in a supine position; an incision was made left of the trachea. Blunt dissection was performed to expose the skull base, and a craniotomy in the occipital bone allowed for access to the medullary pyramids. The dura mater overlaying the pyramids was pierced with a 32-gauge hypodermic needle, and the left or right pyramid was cut with fine iridectomy scissors medially up to the basilar artery (Thallmair et al., 1998; Benowitz et al., 1999). The wound was closed in layers with $5.0 \mathrm{Vic}$ ryl. Then 4 weeks later the intact CST was traced with biotinylated dextran amine (BDA; $1.5 \mu$ l total) infused into the sensorimotor cortex at four sites (coordinates from bregma: $1.0 \mathrm{~mm}$ anterior/1.0 $\mathrm{mm}$ lateral, 1.0 $\mathrm{mm}$ anterior $/ 0.5 \mathrm{~mm}$ lateral, $1.0 \mathrm{~mm}$ posterior/ $1.0 \mathrm{~mm}$ lateral, and $1.0 \mathrm{~mm}$ posterior/0.5 $\mathrm{mm}$ lateral, all at a depth of $0.8 \mathrm{~mm}$ into cortex). Animals received postoperative ampicillin twice a day for $3 \mathrm{~d}$. The surgeon was blind to mouse genotype at surgery. All surgical procedures and postoperative care were performed in accordance with guidelines of the Yale Animal Care and Use Committee.

Behavior. Fine motor skill was assessed in animals that underwent unilateral pyramidotomy by using a modified food pellet retrieval task (Thallmair et al., 1998). Animals were trained daily for 2 weeks before pyramidotomy to retrieve and consume 10 food pellets from a smooth surface through a small window displaced to one side of a transparent plastic box. Pellet retrieval was judged as successful if the animal clearly extended its forelimb through the window, grasped the pellet after paw pronation, retrieved the pellet after paw supination, and consumed it. Pellets swept into the testing box were not counted. The biased location of the aperture in the box resulted in animals preferentially and consistently using one forelimb to retrieve food pellets. $\mathrm{Ngrl}^{-/-}$and $\mathrm{ngrl}^{+/+}$mice were trained to retrieve food pellets with their left forelimbs and subsequently underwent ablation of the right pyramidal tract. The nogo- $a b^{\text {atg/atg }}$ mice and their wild-type littermates were trained to retrieve food pellets with their right forelimbs and subsequently underwent a left pyramid ablation. The choice of a right-sided versus left-sided focus in the two experiments was arbitrary. Animals in all groups displayed clear unilateral limb paresis immediately after recovering from anesthesia. Therefore, within the first day after surgery the mice were unable to perform the food pellet retrieval, regardless of 
genotype. By $28 \mathrm{~d}$ after lesion all animals were capable of retrieving 10 food pellets within a 5 min time span. However, they tended to avoid use of the lesioned paw, instead reaching across with the intact paw. The fraction of 10 pellets successfully retrieved by the lesion-affected paw was scored by an observer unaware of mouse genotype.

Histology. Animals were perfused transcardially with PBS, followed by $4 \%$ paraformaldehyde/PBS. Spinal cords were dissected, postfixed overnight at $4^{\circ} \mathrm{C}$, and embedded for vibratome sectioning. Transverse sections of cervical cord $(25-30 \mu \mathrm{m})$ were processed for BDA with streptavidin secondary antibodies (Invitrogen, Eugene, OR) and tyramide signal amplification (PerkinElmer Life Sciences, Emeryville, CA). Immunofluorescence of brainstem and spinal cord sections used primary antibodies directed to 5-hydroxytryptamine (5-HT; 1:15,000; ImmunoStar, Hudson, WI), glial fibrillary acidic protein (GFAP; 1:10,000; Invitrogen), myelin basic protein (MBP; 1:5000; Invitrogen), protein kinase $\mathrm{C} \gamma(\mathrm{PKC} \gamma$; 1:1000; Santa Cruz Biotechnology, Santa Cruz, $\mathrm{CA})$, and calcitonin gene-related peptide (CGRP; 1:8000; Sigma, St. Louis, MO) with Alexa Fluor 350, 488, and 568 (1:500; Invitrogen) secondary antibodies.

The extent of CST fiber innervation was determined by using NIH ImageJ, version 1.62 (National Institutes of Health, Bethesda, MD). The optical density of BDA reactivity was measured from the pial surface ventrally through transverse spinal cord sections. Alternatively, labeled fibers were selected by thresholding, and fiber length within gray matter from each side of each section (five sections/mouse) was measured after the skeletonize function was used.

\section{Results}

Unilateral pyramidotomy ablates CST input contralaterally in the spinal cord

The absence of long-distance CST regeneration after dorsal hemisection in the nogo-ab $b^{\text {atg/atg }}$ and $n g r 1^{-/-}$mice begs the question as to whether there is a total absence of an enhanced CST axonal growth phenotype in these animals. We turned to another lesion paradigm that would reduce nonmyelin inhibition by astrocytic scars and would entail behavioral recovery more closely linked to CST function. Unilateral lesions of the medullary pyramid (pyramidotomy, PyX) (Fig. $1 A, B$ ) deafferent the contralateral spinal cord of CST input (Thallmair et al., 1998; Benowitz et al., 1999; Starkey et al., 2005). There is a discrete astrocytic response restricted to one side of the ventral medulla (Fig. 1C,D, GFAP-immunoreactive), but there is no change in myelin or astrocytic staining in the cervical spinal cord (Fig. 1, compare $E, F$ ). PyX eliminates PKC $\gamma$ immunoreactivity in the CST on the lesioned side but does not alter the projection of the uninjured CST revealed by either PKC $\gamma$ staining or BDA tracing from cortical injections (Fig. $1 E-H)$.

G for $n=7-10$ mice.
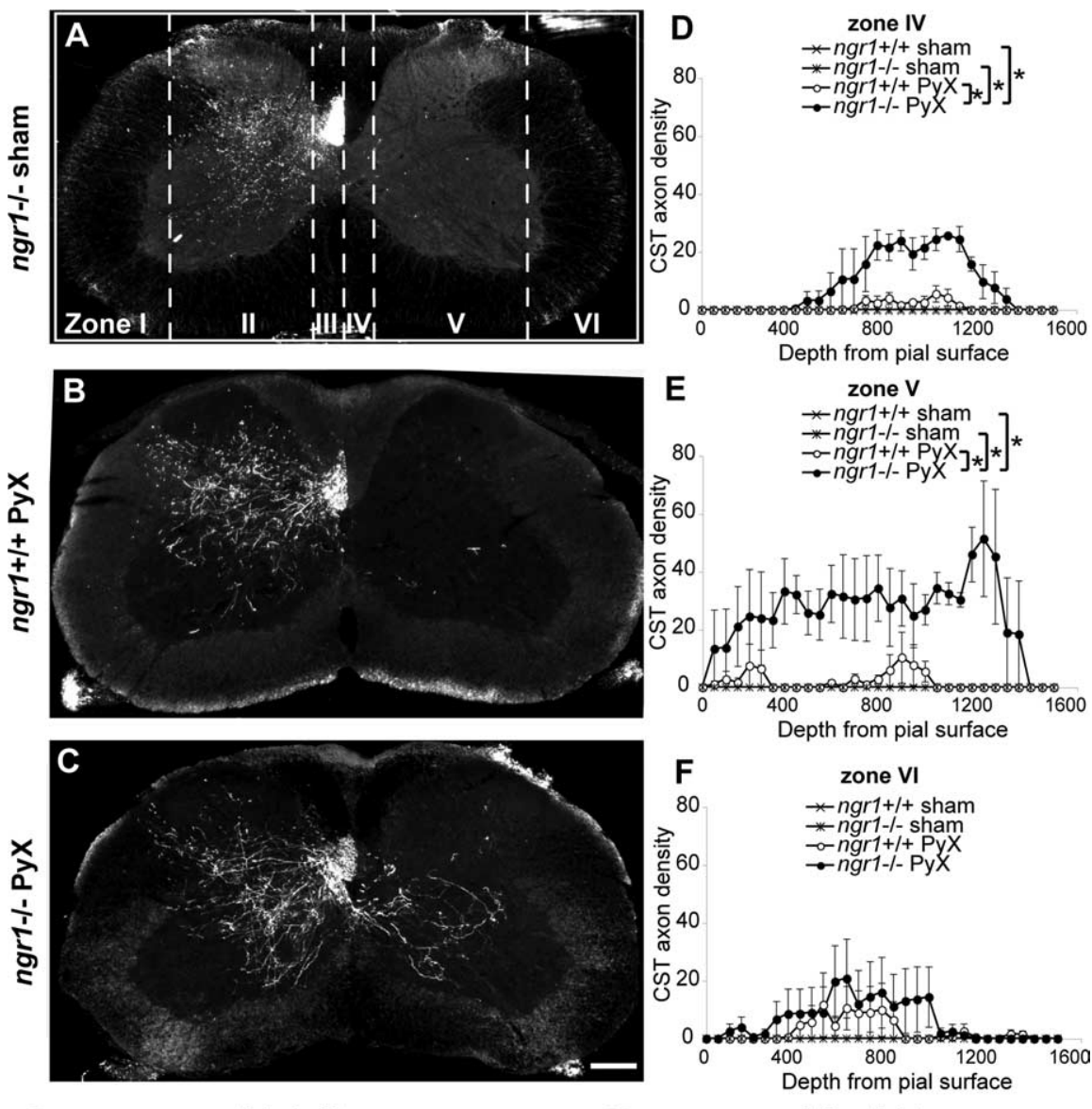

H

Injured side
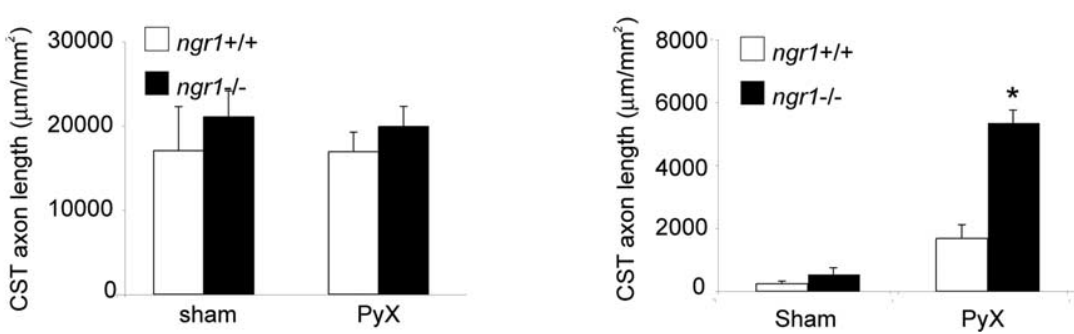

Figure 2. PyX-induced sprouting of intact CST fibers in $n g r 1^{-1-}$ mice. Photomicrographs $A-C$ illustrate $C 7$ transverse sections of spinal cord from $n g r 1^{-/-}$sham, $n g r 1^{+/+}$PyX, and $n g r 1^{-/-}$PyX-lesioned animals. Fasciculated BDA ${ }^{+}$axons can be seen in the left ventrodorsal column $(\boldsymbol{A})$ from which CST collaterals project unilaterally into both dorsal and ventral horns in sham-lesioned $n g r 1^{-/-}(\boldsymbol{A})$ and PyX $n g r 1^{+/+}$mice $(\boldsymbol{B})$. PyX $n g r 1^{-/-}$mice illustrate robust sprouting of intact BDA ${ }^{+}$CST axons into the deafferented side of the spinal cord (C). Scale bar, $100 \mu \mathrm{m}$. The optical density of BDA ${ }^{+}$axons from the pial surface into gray matter was assessed in zones I-VI (A). Quantification of zones IV-VI is shown in $\boldsymbol{D}-\boldsymbol{F}$. The integrated CST density (area under the curve) of $n g r 1^{-/-}$animals is significantly greater in zones IV and $\mathrm{V}$ than in sham-lesioned or PyX $n g r 1^{+/+}$mice $\left({ }^{*} p<0.05\right.$, ANOVA). $\boldsymbol{G}, \boldsymbol{H}$, As another measure of (ST innervation, fiber length per cross-sectional area was measured throughout the spinal cord gray matter. Fiber length was not significantly different on the intact side between $n g \mathrm{r}^{+/+}$and $n g r 1^{-/-}$mice after sham or PyX lesion (G); however, CST fiber length was significantly greater on the injured side of $n g r 1^{-/-}$mice $(\boldsymbol{H})$ compared with $n g r 1^{+/+}$PyX, $n g r 1^{-/-}$sham, and $n g r 1^{+/+}$sham-lesioned mice $\left({ }^{*} p<0.001\right.$, ANOVA). For $\mathbf{G}$ and $\boldsymbol{H}$, data are the mean \pm SEM

PyX-induced sprouting of intact CST fibers in $n g r 1^{-/-}$mice Using the PyX model, we examined injury-induced axon growth in mice lacking the high-affinity receptor for Nogo-A, NgR1 (Kim et al., 2004). Sprouting of intact CST axons was assessed via cortical tracing with BDA injection into the intact cortex 4 weeks after injury. Intact $n g r 1^{+/+}$(Fig. $1 E$ ) and $n g r 1^{-/-}$(Fig. $2 A$ ) mice show normal termination of corticospinal collaterals that branch unilaterally from the main dorsal CST into all lamina of the gray matter. PyX of $n g r 1^{+/+}$mice causes an insignificant change in the 

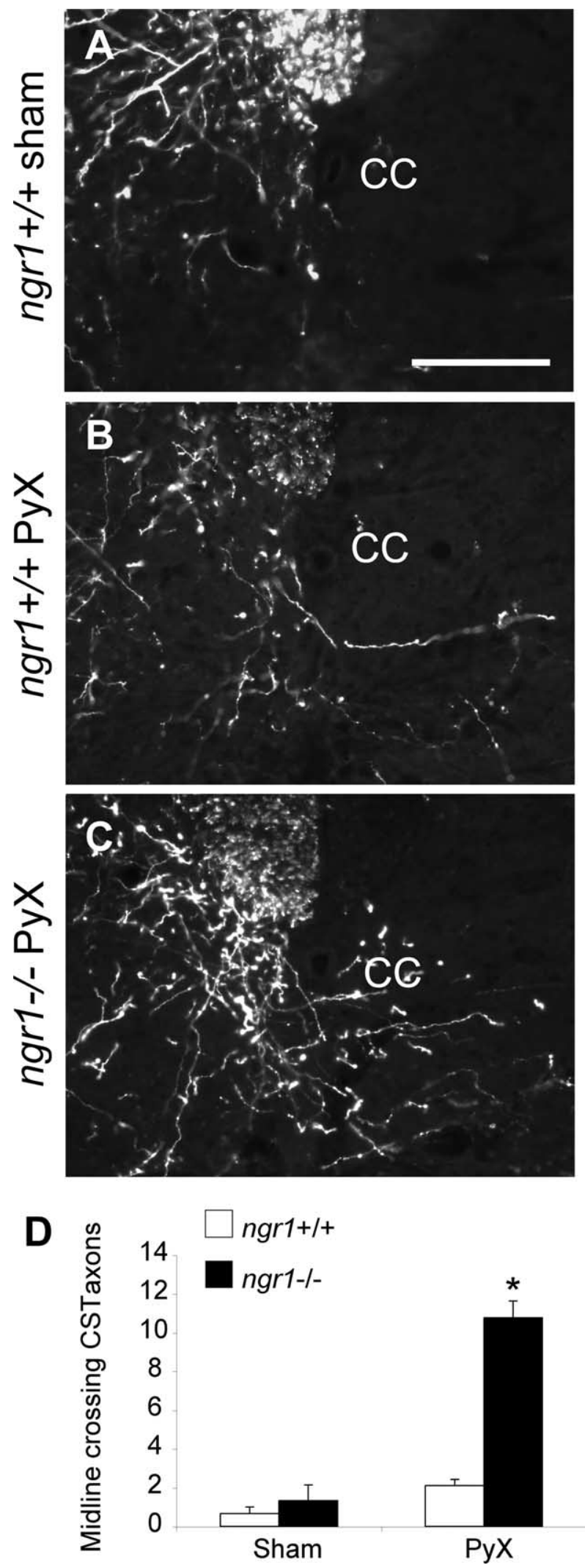

Figure 3. CST fibers crossing the midline of the spinal cord. $A-C$, Photomicrographs illustrate significant numbers of BDA-immunoreactive CST axons sprouting across the midline in $n g r 1^{-/-}$mice after PyX compared with $n g r 1^{-/}$sham and $n g r 1^{+/+}$PyX-lesioned mice. Scale bar, $100 \mu \mathrm{m}$. D, The average number of CST fibers crossing the midline of the cervical spinal per transverse section is significantly greater in $n g r 1^{-1-}$ mice compared with $n g r 1^{+/+}$PyX $n g r 1^{-/}$sham, and $n g r 1^{+/+}$sham-lesioned mice $\left({ }^{*} p<0.001\right.$, ANOVA). Data are the mean \pm SEM for $n=7-10$ mice. termination pattern of BDA-labeled CST collaterals, with most axons remaining ipsilateral to the lesion (Fig. $2 \mathrm{~B}$ ). In marked contrast, PyX in $n g r 1^{-/-}$mice results in substantial sprouting of BDA-labeled CST collaterals across the midline and into the denervated side of the spinal cord (Fig. 2C). The reproducibility of this phenotype is illustrated in supplemental Figure $S 1$ (available at www.jneurosci.org as supplemental material). To quantify this sprouting response, we split the spinal cord into zones I-VI (Fig. $2 \mathrm{~A}$ ) and measured the optical density of BDA reactivity in a vertical plane from the pial surface to the ventral aspect of the spinal cord. CST axon density for the denervated zones IV-VI (Fig. $2 D-F$ ) clearly illustrates the large increase in BDA-labeled axons in the denervated spinal cord after PyX in $n g r 1^{-/-}$mice, but not in $n g r 1^{+/+}$mice. Measurement of CST axonal length in the transverse plane yields similar evidence for injury-induced axonal growth into the denervated side of the spinal cord of $n g r 1^{-/-}$ mice (Fig. $2 \mathrm{H}$ ). In fact, this growth reconstitutes $25 \%$ of normal innervation density (Fig. 2, compare $G, H$ ). We directly counted the number of CST fibers crossing from the intact side of the spinal cord to the denervated side within midcervical transverse sections. Animals lacking ngrl exhibit a fivefold increase in the absolute incidence of such crossing CST axons (Fig. 3).

Given the extensive growth from uninjured CST fibers into denervated spinal cord, an improved recovery of the fine motor function may be expected in $n g r 1^{-/-}$mice if fibers from the ipsilateral, "wrong," cortex can contribute to functional recovery. Adult $n g r 1^{+/+}$and $n g r 1^{-/-}$mice were trained to retrieve food pellets through a small window in transparent plastic box, with the window displaced to one wall of the box such that animals were biased to use one paw to retrieve food. The mice then underwent unilateral PyX to deafferent the spinal cord on the side of the pretrained forelimb. In the first day after surgery the affected forelimb was paretic and mice were not subjected to the food pellet retrieval test. Animals recovered function over 4 weeks, at which time their preference for retrieving food pellets with their injury-affected versus unaffected forelimbs was reassessed. The control $n g r 1^{+/+}$mice were able to retrieve food pellets at 4 weeks after PyX, but they did so almost exclusively by reaching across with the unaffected forelimb and made little use of the previously trained limb (see Fig. 6). In stark contrast, the $n g r 1^{-/-}$mice fully regained the preferential use of the affected forelimb and were indistinguishable from sham-lesioned animals at the end of the recovery period. Thus the adult $n g r 1^{-/-}$mice are capable of CST growth to an extent that wild-type mice are not. Moreover, this CST growth appears to be capable of promoting functionally relevant behaviors.

\section{PyX-induced sprouting of intact CST fibers in nogo- $\boldsymbol{a b}^{\text {atg/atg }}$ mice}

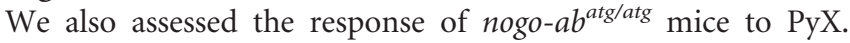
Sprouting of intact CST axons was monitored by BDA tracing in lesioned adult nogo-ab $b^{+/+}$and nogo-ab atg/atg mice. Shamlesioned nogo-ab atg/atg mice have normal CST terminals in contralateral gray matter (Fig. $4 A$ ). As expected, PyX in nogo- $a b^{+/+}$ mice does not alter the spatial location of CST terminals significantly (Fig. $4 B$ ). In contrast, pyramid lesion in nogo-ab $b^{\text {atg/atg }}$ mice results in the sprouting of substantial numbers of CST axons from the intact to the denervated side (Fig. 4C). This pattern was observed consistently (supplemental Fig. S2, available at www. jneurosci.org as supplemental material). Quantification of CST axon density in the dorsoventral plane in zones I-VI (Fig. 4A) reveals nogo-ab atg/atg mice to have significantly more BDAlabeled fibers present in all denervated zones (Fig. 4D-F). CST 
axonal arbor length is increased selectively on the denervated side (Fig. 4G,H), and CST midline crossings are much more numerous in cervical spinal cord sections from nogo-ab $b^{\text {atg/atg }}$ mice (Fig. 5).

The adult nogo- $a b^{+/+}$and nogo-ab atg/atg mice had been trained in the food pellet retrieval task for 2 weeks before PyX. At 4 weeks after surgery their preference for retrieving food pellets with their affected forelimb was assessed. Control nogo$a b^{+/+}$mice did not use their injured forelimbs to retrieve food pellets at the end of the testing period. The nogo- $a b^{\text {atg/atg }}$ mice fully recovered preferential use of the deafferented forelimb by 4 weeks after lesion and were indistinguishable from sham surgery mice (Fig. 6B).

\section{PyX does not alter primary afferent terminals or descending raphespinal axons}

The preceding PyX studies demonstrate robust sprouting of uninjured $n g r 1^{-/-}$ and nogo-ab ${ }^{\text {atg/atg }}$ CST axons adjacent to a denervated contralateral spinal cord. On the one hand, this growth may reflect a focal and selectively beneficial responsiveness of spared CST fibers. Alternatively, the PyX may release the growth of multiple fiber systems in the cervical spinal cord without respect to functional consequence. Consistent with the latter notion, previous reports have shown that unilateral PyX results in the dysregulation of a number of genes within the denervated side of the spinal cord (Bareyre et al., 2002), including an upregulation of brainderived neurotrophic factor (BDNF) that may have pleiotropic axonal growth effects. To assess the specificity of PyXinduced axonal growth in the $n g r 1^{-/-}$and nogo-ab $b^{\text {atg/atg }}$ mice, we investigated two other fiber systems: primary afferent nociceptors (expressing CGRP) and raphespinal fibers. CGRP-immunoreactive sensory neurons terminate in lamina II of spinal gray matter on the intact and pyramidotomized side in $n g r 1^{+/+}$and nogo-ab $b^{+/+}$ mice (Fig. $7 A, H$, left side intact). CGRP nociceptors have a normal termination pattern on the intact side of $n g r 1^{-/-}$and nogo-ab atg/atg mice, and the pattern of CGRP-immunoreactive terminals is unchanged by PyX in $n g r 1^{-/-}$or nogo-ab atg/atg mice (Fig. 7B,I, left side intact). Quantification of axon density shows there is no significant difference between $n g r 1^{+/+}$and $n g r 1^{-/-}$mice and nogo- $a b^{+/+}$and nogo- $a b^{\text {atg/atg }}$ mice on the intact side (Fig. $7 C, J$ ) or the pyramidotomized side (Fig. $7 D, K$ ).

Raphespinal axons terminate in a diffuse manner throughout the ventral horn and are concentrated in superficial lamina in the dorsal horn in the cervical spinal cord. 5-HT-immunoreactive raphespinal terminals are bilaterally symmetrical after PyX in the
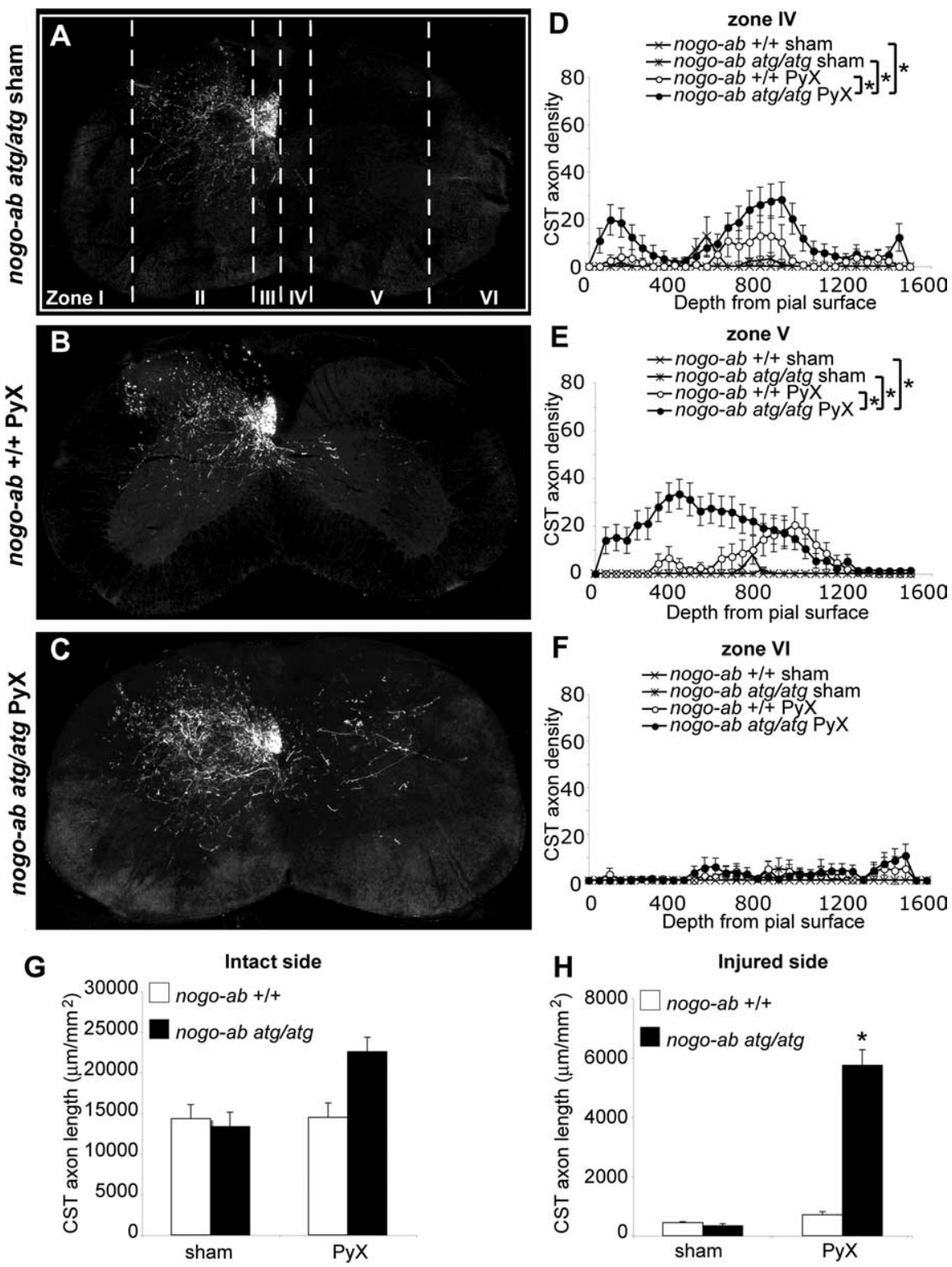

Figure 4. PyX-induced sprouting of intact CST fibers in nogo-a $b^{\text {atg/atg }}$ mice. Photomicrographs $\boldsymbol{A}-\boldsymbol{C}$ illustrate $\mathrm{C} 7$ transverse section of spinal cord from nogo-a $b^{\text {atg/atg }}$ sham, nogo- $a b^{+/+}$PyX, and nogo-a $a b^{\text {atg/atg }}$ PyX-lesioned animals, respectively. Fasciculated $\mathrm{BDA}^{+}$axons can be seen in the left ventrodorsal column $(\boldsymbol{A})$ from which CST collaterals project unilaterally into both dorsal and ventral horns in sham-lesioned nogo-ab $b^{a t g / a t g}(\boldsymbol{A})$ and PyX nogo- $a b^{+/+}$mice (B). PyX nogo-ab $b^{a t g / a t g}$ mice illustrated increased sprouting of intact BDA ${ }^{+}$CST axons into the deafferented side of the spinal cord (C). Scale bar, $200 \mu \mathrm{m}$. The optical density of BDA reactivity from the pial surface into gray matter was assessed in zones $I-V I(A)$. Quantification of zones IV-VI is shown in $\boldsymbol{D}-\boldsymbol{F}$. Assessment of the integrated axonal density (area under the curve) revealed that nogo-ab atg/atg animals have significantly more BDA reactivity in zones IV and V in comparison to sham-lesioned and PyX nogo-ab ${ }^{+/+}$mice $\left({ }^{*} p<0.05\right.$, ANOVA). $\boldsymbol{G}, \boldsymbol{H}$, The absolute length of (ST axon per cross-sectional area was measured throughout the spinal cord gray matter for each condition. Fiber length was not significantly different on the intact side between nogo- $a b^{+/+}$sham and nogo-ab $b^{+/+}$ PyX-lesioned mice (G). However, PyX-lesioned $n g r 1^{-1-}$ mice had significantly greater CST length compared with nogo-ab atg/atg sham-lesioned mice $\left({ }^{*} p<0.05\right.$, ANOVA). CST fiber length was also significantly greater on the injured side of nogo-ab ${ }^{\text {atg/atg }}$ mice (H) compared with nogo-ab ${ }^{+/+}$PyX, nogo-abatg/atg sham, and nogo-ab ${ }^{+/+}$sham-lesioned mice $\left({ }^{*} p<0.001\right.$, ANOVA). For $\mathbf{G}$, $\boldsymbol{H}$, data are the mean \pm SEM for $n=7-10$ mice.

dorsal horn (data not shown) and ventral horn in $n g r 1^{+/+}$and nogo- $a b^{+/+}$mice (Fig. $7 E, L$, left side intact). 5-HTimmunoreactive terminals normally are distributed in the dorsal horn (data not shown) and ventral horn on the intact side in $n g r 1^{-1-}$ and nogo-ab $b^{\text {atg/atg }}$ mice and appear to be unchanged after PyX (Fig. $7 F, M$, left side intact). Quantification of the average total length of 5-HT fibers present in the dorsal horn and ventral horn shows that there is no significant difference between 

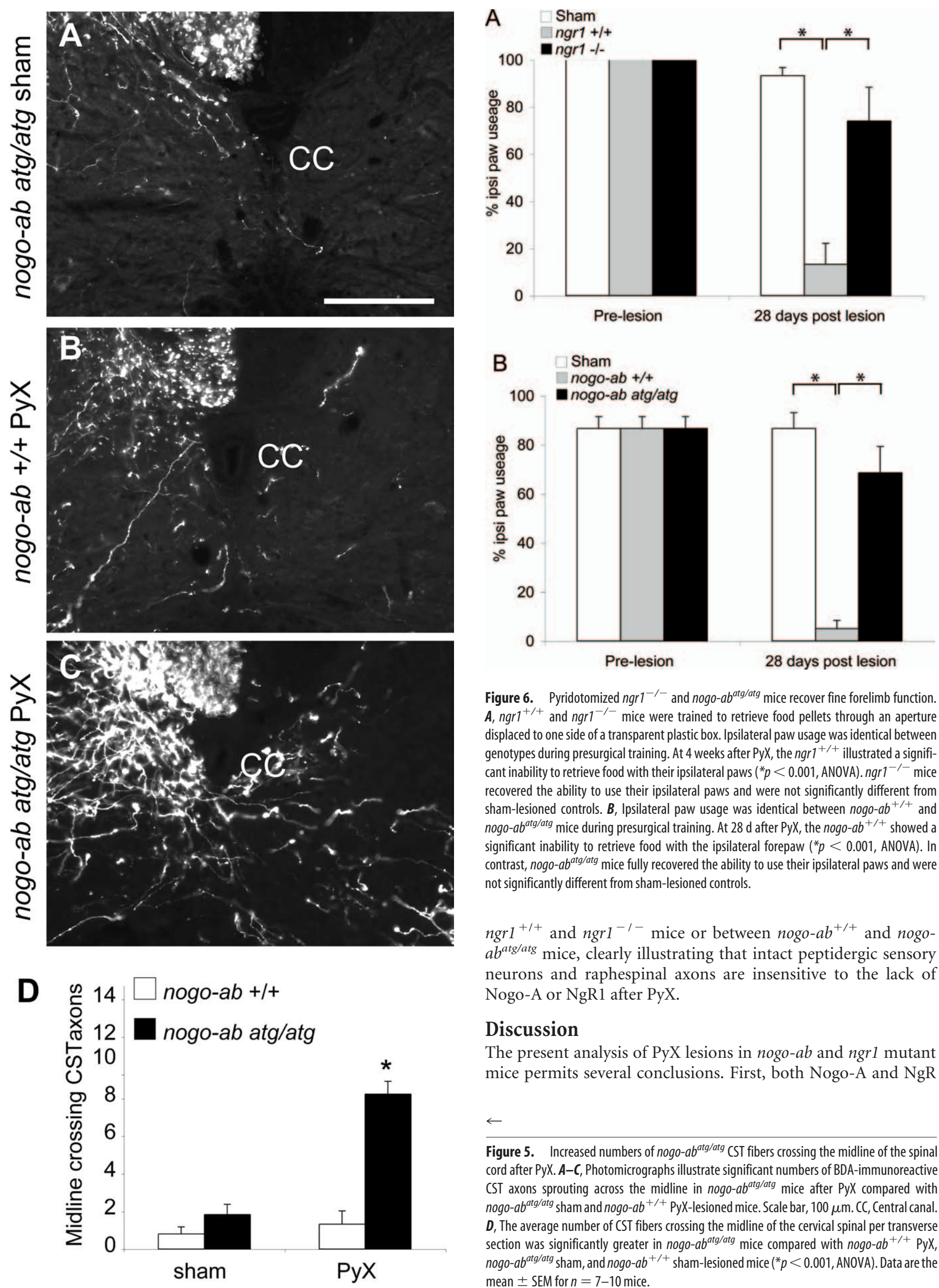

Figure 6. Pyridotomized $n g r 1^{-/-}$and nogo-ab $b^{\text {atg/atg }}$ mice recover fine forelimb function. $A, n g r 1^{+/+}$and $n g r 1^{-/-}$mice were trained to retrieve food pellets through an aperture displaced to one side of a transparent plastic box. Ipsilateral paw usage was identical between genotypes during presurgical training. At 4 weeks after PyX, the $n g r 1^{+/+}$illustrated a significant inability to retrieve food with their ipsilateral paws ( ${ }^{*} p<0.001$, ANOVA). $n g r 1^{-1-}$ mice recovered the ability to use their ipsilateral paws and were not significantly different from sham-lesioned controls. B, Ipsilateral paw usage was identical between nogo- $a b^{+/+}$and nogo-a $b^{\text {atg/atg }}$ mice during presurgical training. At $28 \mathrm{~d}$ after PyX, the nogo- $a b^{+/+}$showed a significant inability to retrieve food with the ipsilateral forepaw ( ${ }^{*} p<0.001$, ANOVA). In contrast, nogo-a $b^{a t g / a t g}$ mice fully recovered the ability to use their ipsilateral paws and were not significantly different from sham-lesioned controls.

$n g r 1^{+/+}$and $n g r 1^{-1-}$ mice or between nogo-ab ${ }^{+/+}$and nogo$a b^{\text {atg/atg }}$ mice, clearly illustrating that intact peptidergic sensory neurons and raphespinal axons are insensitive to the lack of Nogo-A or NgR1 after PyX.

\section{Discussion}

The present analysis of PyX lesions in nogo-ab and ngr1 mutant mice permits several conclusions. First, both Nogo-A and NgR

Figure 5. Increased numbers of nogo-ab atg/atg CST fibers crossing the midline of the spinal cord after PyX. A-C, Photomicrographs illustrate significant numbers of BDA-immunoreactive CST axons sprouting across the midline in nogo-ab atg/atg mice after PyX compared with nogo-ab $b^{\text {atg/atg }}$ sham and nogo- $a b^{+/+}$PyX-lesioned mice. Scale bar, $100 \mu \mathrm{m}$. CC, Central canal. $D$, The average number of CST fibers crossing the midline of the cervical spinal per transverse section was significantly greater in nogo-ab $b^{\text {atg/atg }}$ mice compared with nogo- $a b^{+/+}$PyX, nogo-ab $b^{\text {atg/atg }}$ sham, and nogo- $a b^{+/+}$sham-lesioned mice $\left({ }^{*} p<0.001\right.$, ANOVA). Data are the mean \pm SEM for $n=7-10$ mice. 
play a genetically confirmed role in limiting injury-induced CST axon growth in vivo. Second, injury-induced adult axonal growth is a graded phenomenon that varies between fiber tract and lesion paradigm and occurs in several forms ranging from collateral sprouting to long-distance regeneration. Third, the penetrance of the nogo- $a b$ null-enhanced growth phenotype is modifiable not only by age (Kim et al., 2003), specific nogo-ab mutant allele (Zheng et al., 2003) (our unpublished studies), and background strain (Dimou et al., 2006) but also by the nature of the CNS lesion.

\section{A spectrum of injury-induced axonal growth}

Both nogo-ab $b^{\text {atg/atg }}$ mice and $n g r 1^{-/-}$mice exhibit significant sprouting of intact corticospinal axons into denervated spinal cord after unilateral PyX, despite the absence of long-distance CST regeneration after dorsal hemisection. Injury-induced axonal growth can be classified both by anatomical tract and by the type of growth. Descending fiber tracts participating in motor control include CST, raphespinal, rubrospinal, and reticulospinal. Studies with various manipulations of the $\mathrm{NgR}$ system indicate that the serotonergic raphespinal fibers are most capable of injury-induced growth, rubrospinal axons are intermediate, and the CST system is least capable of growth after injury. This relative growth scale may be specific to conditions reducing Nogo/NgR function or may reflect the intrinsic growth state of these different neuronal populations.

Several modes of injury-induced axonal growth can occur. In a regenerative mode the growth extends from severed fibers into distal territory. In collateral sprouting the fibers branch from existing intact tracts, commonly into a territory denervated by axotomy. Regenerative sprouting describes growth from axotomized axons that remain proximal to a lesion site. If we use these terms, the growth of CST fibers in nogo-ab trap/trap mice includes regenerative growth and regenerative sprouting (Kim et al., 2004). The CST fibers of nogo-ab $b^{\text {atg/atg }}$ mice exhibit collateral sprouting not found in wild-type mice (Figs. 4, 5), but there is not regenerative CST growth (Zheng et al., 2003) (our unpublished studies). In $n g r 1^{-/-}$mice there is regenerative growth of raphespinal and rubrospinal fibers, whereas CST fibers exhibit collateral sprouting (Figs. 2, 3) and no regenerative growth (Kim et al., 2004). Pharmacological studies with anti-Nogo antibodies, the Nogo extracellular peptide residues 1-40 (NEP1-40) antagonist peptide, and soluble $\operatorname{NgR}(310)$ ectodomain-Fc protein have each demonstrated regenerative growth, collateral sprouting, and regenerative sprouting of cortibar, $200 \mu \mathrm{m}$.
PyX
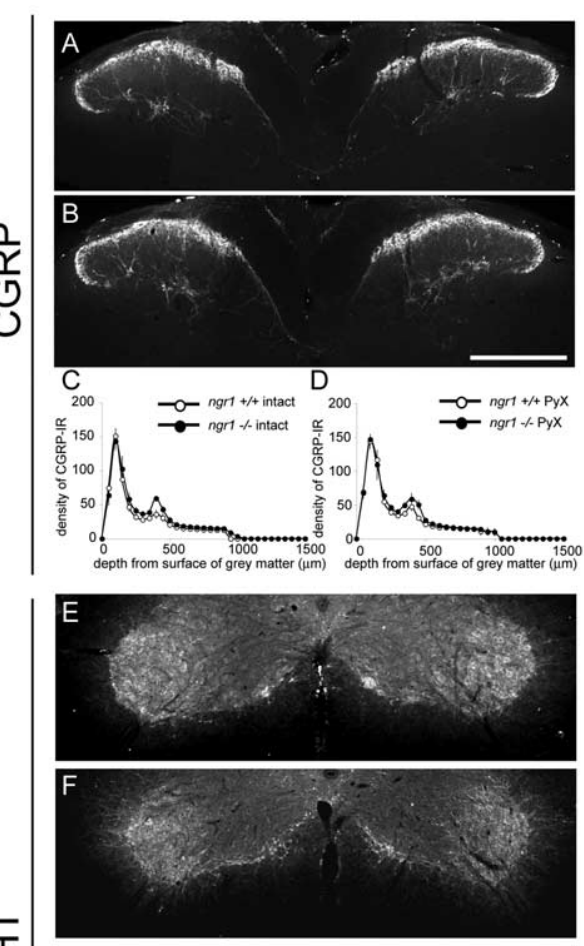

G

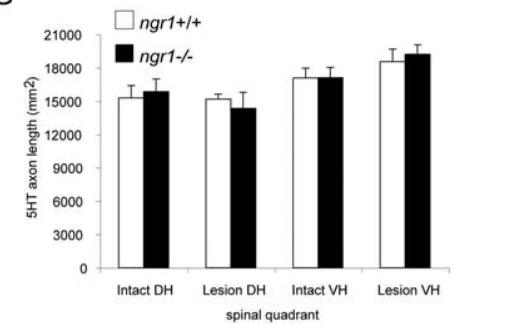

ngr1
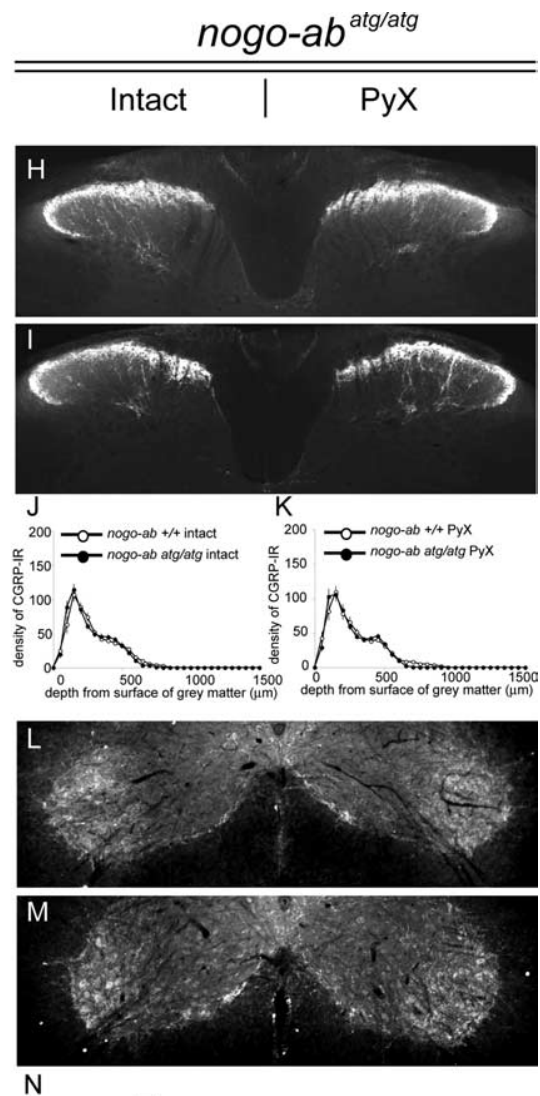

$\mathrm{N}$

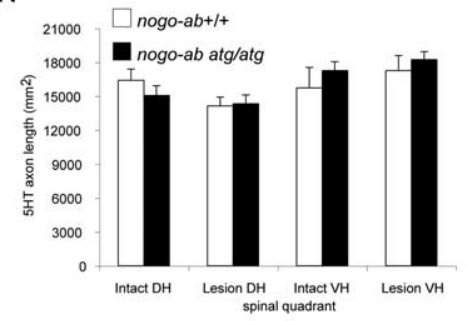

Figure 7. PyX fails to influence wiring of primary afferent terminals or descending raphe axons. Photomicrographs show transverse sections of C7 spinal cord (dorsal horn) immunostained for CGRP from $n g r 1^{+/+}(\boldsymbol{A})$ and $n g r 1^{-/-}(\boldsymbol{B})$ mice after PyX (left side intact). Scale bar, $200 \mu \mathrm{m}$. Assessment of CGRP axon density illustrates normal termination pattern (lamina II) in $n g r 1^{+/+}(\boldsymbol{C})$ and $n g r 1^{-/-}(\boldsymbol{D})$ mice. PyX does not result in primary afferent reorganization in $n g r 1^{+/+}$or $n g r 1^{-/-}$mice. Also shown are photomicrographs of C7 spinal cord (ventral horn) immunostained for 5 -HT from $n g r 1^{+/+}(\boldsymbol{E})$ and $n g r 1^{-/-}(\boldsymbol{F})$ mice after PyX (left side intact). No significant difference is found in 5-HT-immunoreactive spatial axon density in dorsal or ventral horn of $n g r 1^{+/+}$or $n g r 1^{-/-}$mice after PyX (G). Photomicrographs show transverse sections of C7 spinal cord (dorsal horn) immunostained for CGRP from nogo- $a b^{+/+}(\boldsymbol{H})$ and nogo-ab atg/atg $(\boldsymbol{I})$ mice after PyX (left side intact). Assessment of CGRP axon density illustrates normal termination pattern (lamina II) in nogo- $a b^{+/+}(\boldsymbol{J})$ and nogo- $a b^{\text {atg/atg }}(\boldsymbol{K})$ mice. PyX does not result in primary afferent reorganization in nogo- $a b^{+/+}$or nogo-ab atg/atg . Also shown are photomicrographs of $\mathrm{C} 7$ spinal cord (ventral horn) immunostained for 5-HT from nogo- $a b^{+/+}(\boldsymbol{L})$ and nogo- $a b^{a t g / a t g}(\boldsymbol{M})$ mice after PyX (left side intact). No significant difference is found in 5-HT-immunoreactive axon density in dorsal or ventral horn of nogo- $a b^{+/+}$or nogo- $a b^{\text {atg } / a t g}$ mice after PyX $(\boldsymbol{N})$. Scale

cofugal fibers and raphespinal systems (Schnell and Schwab, 1990; GrandPre et al., 2002; Li and Strittmatter, 2003). It is critical that genetic studies of other components of the Nogo/NgR system and of other pathways be extended across this spectrum of growth. Caution in extrapolating from any one model must be exercised (Woolf, 2003).

\section{PyX-induced sprouting of the CST}

The growth of CST axons in nogo- $a b^{\text {atg/atg }}$ and $n g r 1^{-/-}$mice after $\mathrm{PyX}$, but not after dorsal hemisection, is striking. The difference between models may relate to the relative role played by astrocytic scars. At a hemisection extensive astrocytic hypertrophy, 
proliferation, and deposition of chondroitin sulfate proteoglycans occur. In contrast, the cervical spinal cord through which collateral CST sprouts grow after PyX exhibits no reactive astrogliosis; however, myelin persists. Thus this model more specifically may isolate oligodendrocyte- from astrocyte-mediated inhibition of adult axonal growth.

Another issue in the PyX model is the nature of the signal that leads to CST collateral growth. There is selectivity in the response because CST axons, but not raphespinal fibers or CGRPimmunoreactive primary afferents, exhibit sprouting. Because the sprouting occurs at a site distant from the lesion, the most proximate potential signal for growth is a ventral horn denervated of descending CST input. How contralateral CST axons might sense an altered electrophysiological or biochemical state within the segmental spinal cord remains an open question. A previous analysis of PyX-induced gene dysregulation revealed that a number of growth-related proteins, growth factors, and guidance molecules are upregulated in the denervated spinal cord (Bareyre et al., 2002).

When CST fibers exhibit collateral sprouts, there is a recovery of paw preference in the food pellet retrieval task. To the extent that the midline-crossing anatomical sprouts contribute to functional improvement, the cerebral cortex ipsilateral to the affected forelimb is implicated in motor recovery. However, the mechanism for the behavioral recovery in $n g r 1^{-1-}$ and nogo-ab atg/atg mice also may lie in plastic changes reported in the lesioned CST. Previous studies have illustrated that novel connections arise from the damaged CST to the red nucleus and pontomedullary formation after PyX and IN-1 treatment (Thallmair et al., 1998). Although these connections allow lesioned CST fibers access to the denervated spinal cord, it seems that these connections fail to impact the recovery of function, because re-lesioning the damaged CST proximal to the original lesion site failed to diminish the recovery observed in the food pellet retrieval in mice that had received IN-1 after PyX (Thallmair et al., 1998). Therefore, although we cannot rule out the possibility that corticofugal reorganization can contribute to behavioral recovery in PyX $n g r 1^{-/-}$ and nogo-ab $b^{\text {atg/atg }}$ mice, our current data correlate contralateral corticospinal sprouting with recovery of motor function. This is consistent with human stroke cases in which recovered function can be redistributed to new alternate pathways, as demonstrated by functional magnetic resonance imaging. For example, partial recovery from the contralateral hemiparesis associated with a motor cortex stroke can involve activation of regions in the opposite, undamaged hemisphere (Pineiro et al., 2001; Feydy et al., 2002; Foltys et al., 2003; Zemke et al., 2003). In conclusion, these data confirm a key role the Nogo/NgR axis in limiting axonal growth after CNS injury.

\section{References}

Acevedo L, Yu J, Erdjument-Bromage H, Miao RQ, Kim JE, Fulton D, Tempst P, Strittmatter SM, Sessa WC (2004) A new role for Nogo as a regulator of vascular remodeling. Nat Med 10:382-388.

Bareyre FM, Haudenschild B, Schwab ME (2002) Long-lasting sprouting and gene expression changes induced by the monoclonal antibody IN-1 in the adult spinal cord. J Neurosci 22:7097-7110.

Barton WA, Liu BP, Tzvetkova D, Jeffrey PD, Fournier AE, Sah D, Cate R, Strittmatter SM, Nikolov DB (2003) Structure and axon outgrowth inhibitor binding of the Nogo-66 receptor and related proteins. EMBO J 22:3291-3302.

Benfey M, Aguayo AJ (1982) Extensive elongation of axons from rat brain into peripheral nerve grafts. Nature 296:150-152.

Benowitz LI, Goldberg DE, Madsen JR, Soni D, Irwin N (1999) Inosine stimulates extensive axon collateral growth in the rat corticospinal tract after injury. Proc Natl Acad Sci USA 96:13486-13490.
Benson MD, Romero MI, Lush ME, Lu QR, Henkemeyer M, Parada LF (2005) Ephrin-B3 is a myelin-based inhibitor of neurite outgrowth. Proc Natl Acad Sci USA 102:10694-10699.

Bregman BS, Kunkel-Bagden E, Schnell L, Dai HN, Gao D, Schwab ME (1995) Recovery from spinal cord injury mediated by antibodies to neurite growth inhibitors. Nature 378:498-501.

Chen MS, Huber AB, van der Haar ME, Frank M, Schnell L, Spillmann AA, Christ F, Schwab ME (2000) Nogo-A is a myelin-associated neurite outgrowth inhibitor and an antigen for monoclonal antibody IN-1. Nature 403:434-439.

David S, Aguayo AJ (1981) Axonal elongation into peripheral nervous system "bridges" after central nervous system injury in adult rats. Science 214:931-933.

Dimou L, Schnell L, Montani L, Duncan C, Simonen M, Schneider R, Liebscher T, Gullo M, Schwab ME (2006) Nogo-A-deficient mice reveal strain-dependent differences in axonal regeneration. J Neurosci 26:5591-5603.

Dodd DA, Niederoest B, Bloechlinger S, Dupuis L, Loeffler JP, Schwab ME (2005) Nogo-A, -B, and -C are found on the cell surface and interact together in many different cell types. J Biol Chem 280:12494-12502.

Feydy A, Carlier R, Roby-Brami A, Bussel B, Cazalis F, Pierot L, Burnod Y, Maier MA (2002) Longitudinal study of motor recovery after stroke: recruitment and focusing of brain activation. Stroke 33:1610-1617.

Foltys H, Krings T, Meister IG, Sparing R, Boroojerdi B, Thron A, Topper R (2003) Motor representation in patients rapidly recovering after stroke: a functional magnetic resonance imaging and transcranial magnetic stimulation study. Clin Neurophysiol 114:2404-2415.

Fournier AE, GrandPre T, Strittmatter SM (2001) Identification of a receptor mediating Nogo-66 inhibition of axonal regeneration. Nature 409:341-346.

GrandPre T, Nakamura F, Vartanian T, Strittmatter SM (2000) Identification of the Nogo inhibitor of axon regeneration as a Reticulon protein. Nature 403:439-444.

GrandPre T, Li S, Strittmatter SM (2002) Nogo-66 receptor antagonist peptide promotes axonal regeneration. Nature 417:547-551.

Hu F, Liu BP, Budel S, Liao J, Chin J, Fournier A, Strittmatter SM (2005) Nogo-A interacts with the Nogo-66 receptor through multiple sites to create an isoform-selective subnanomolar agonist. J Neurosci 25:5298-5304.

Kim JE, Li S, GrandPre T, Qiu D, Strittmatter SM (2003) Axon regeneration in young adult mice lacking Nogo-A/B. Neuron 38:187-199.

Kim JE, Liu BP, Park JH, Strittmatter SM (2004) Nogo-66 receptor prevents raphespinal and rubrospinal axon regeneration and limits functional recovery from spinal cord injury. Neuron 44:439-451.

Lee JK, Kim JE, Sivula M, Strittmatter SM (2004) Nogo receptor antagonism promotes stroke recovery by enhancing axonal plasticity. J Neurosci 24:6209-6217.

Li S, Strittmatter SM (2003) Delayed systemic Nogo-66 receptor antagonist promotes recovery from spinal cord injury. J Neurosci 23:4219-4227.

Li S, Liu BP, Budel S, Li M, Ji B, Walus L, Li W, Jirik A, Rabacchi S, Choi E, Worley D, Sah DW, Pepinsky B, Lee D, Relton J, Strittmatter SM (2004) Blockade of Nogo-66, myelin-associated glycoprotein, and oligodendrocyte myelin glycoprotein by soluble Nogo-66 receptor promotes axonal sprouting and recovery after spinal injury. J Neurosci 24:10511-10520.

Liu BP, Fournier A, GrandPre T, Strittmatter SM (2002) Myelin-associated glycoprotein as a functional ligand for the Nogo-66 receptor. Science 297:1190-1193.

McKerracher L, David S, Jackson DL, Kottis V, Dunn RJ, Braun PE (1994) Identification of myelin-associated glycoprotein as a major myelinderived inhibitor of neurite growth. Neuron 13:805-811.

Miao RQ, Gao Y, Harrison KD, Prendergast J, Acevedo LM, Yu J, Hu F, Strittmatter SM, Sessa WC (2006) Identification of a receptor necessary for Nogo-B stimulated chemotaxis and morphogenesis of endothelial cells. Proc Natl Acad Sci USA 103:10997-11002.

Mukhopadhyay G, Doherty P, Walsh FS, Crocker PR, Filbin MT (1994) A novel role for myelin-associated glycoprotein as an inhibitor of axonal regeneration. Neuron 13:757-767.

Oertle T, van der Haar ME, Bandtlow CE, Robeva A, Burfeind P, Buss A, Huber AB, Simonen M, Schnell L, Brosamle C, Kaupmann K, Vallon R, Schwab ME (2003) Nogo-A inhibits neurite outgrowth and cell spreading with three discrete regions. J Neurosci 23:5393-5406.

Papadopoulos CM, Tsai SY, Alsbiei T, O’Brien TE, Schwab ME, Kartje GL 
(2002) Functional recovery and neuroanatomical plasticity following middle cerebral artery occlusion and IN-1 antibody treatment in the adult rat. Ann Neurol 51:433-441.

Pineiro R, Pendlebury S, Johansen-Berg H, Matthews PM (2001) Functional MRI detects posterior shifts in primary sensorimotor cortex activation after stroke: evidence of local adaptive reorganization? Stroke 32:1134-1139.

Prinjha R, Moore SE, Vinson M, Blake S, Morrow R, Christie G, Michalovich D, Simmons DL, Walsh FS (2000) Inhibitor of neurite outgrowth in humans. Nature 403:383-384.

Schnell L, Schwab ME (1990) Axonal regeneration in the rat spinal cord produced by an antibody against myelin-associated neurite growth inhibitors. Nature 343:269-272.

Seymour AB, Andrews EM, Tsai SY, Markus TM, Bollnow MR, Brenneman MM, O’Brien TE, Castro AJ, Schwab ME, Kartje GL (2005) Delayed treatment with monoclonal antibody IN-1 1 week after stroke results in recovery of function and corticorubral plasticity in adult rats. J Cereb Blood Flow Metab 25:1366-1375.

Simonen M, Pedersen V, Weinmann O, Schnell L, Buss A, Ledermann B, Christ F, Sansig G, van der Putten H, Schwab ME (2003) Systemic deletion of the myelin-associated outgrowth inhibitor Nogo-A improves regenerative and plastic responses after spinal cord injury. Neuron 38:201-211.

Starkey ML, Barritt AW, Yip PK, Davies M, Hamers FP, McMahon SB, Bradbury EJ (2005) Assessing behavioural function following a pyramidotomy lesion of the corticospinal tract in adult mice. Exp Neurol 195:524-539.
Thallmair M, Metz GA, Z'Graggen WJ, Raineteau O, Kartje GL, Schwab ME (1998) Neurite growth inhibitors restrict plasticity and functional recovery following corticospinal tract lesions. Nat Neurosci 1:124-131.

Venkatesh K, Chivatakarn O, Lee H, Joshi PS, Kantor DB, Newman BA, Mage R, Rader C, Giger RJ (2005) The Nogo-66 receptor homolog NgR2 is a sialic acid-dependent receptor selective for myelin-associated glycoprotein. J Neurosci 25:808-822.

Voeltz GK, Prinz WA, Shibata Y, Rist JM, Rapoport TA (2006) A class of membrane proteins shaping the tubular endoplasmic reticulum. Cell 124:573-586.

Wang KC, Koprivica V, Kim JA, Sivasankaran R, Guo Y, Neve RL, He Z (2002) Oligodendrocyte-myelin glycoprotein is a Nogo receptor ligand that inhibits neurite outgrowth. Nature 417:941-944.

Wang X, Chun SJ, Treloar H, Vartanian T, Greer CA, Strittmatter SM (2002) Localization of Nogo-A and Nogo-66 receptor proteins at sites of axonmyelin and synaptic contact. J Neurosci 22:5505-5515.

Woolf CJ (2003) No Nogo: now where to go? Neuron 38:153-156.

Zemke AC, Heagerty PJ, Lee C, Cramer SC (2003) Motor cortex organization after stroke is related to side of stroke and level of recovery. Stroke 34:e23-e28.

Zheng B, Ho C, Li S, Keirstead H, Steward O, Tessier-Lavigne M (2003) Lack of enhanced spinal regeneration in Nogo-deficient mice. Neuron 38:213-224.

Zheng B, Atwal J, Ho C, Case L, He XL, Garcia KC, Steward O, TessierLavigne M (2005) Genetic deletion of the Nogo receptor does not reduce neurite inhibition in vitro or promote corticospinal tract regeneration in vivo. Proc Natl Acad Sci USA 102:1205-1210. 